\title{
19. ICHNOFOSSILS IN DEEP-SEA CORES FROM THE SOUTHWEST PACIFIC
}

\author{
Gerrit J. van der Lingen, Sedimentation Laboratory, New Zealand Geological Survey, Christchurch, New Zealand
}

\section{INTRODUCTION}

Bioturbation is common in most of the sediments cored during Leg 21 of the Deep Sea Drilling Project. Unfortunately, it can only be observed in the more indurated sediments. This means that no comparison can be made from deep-sea drilling cores between ancient and presentday bioturbation.

Ichnofossils (trace fossils) which can be observed in cores are almost exclusively burrows. Because of the restrictions of core diameter and attitude, grazing traces, which are restricted to bedding planes, have never been observed.

The degree of bioturbation varies greatly, from complete reworking, resulting in a mottled appearance (Figures 1 and 2 ), to sparsely distributed, individually recognizable burrows (e.g., Figures 3 and 4). The fill of larger burrows may be reworked by smaller burrowing animals (Figure 2).

Rarely are the burrows diagnostic for a specific ichnogenus. In the cores of Leg 21 only two genera have been recognized with any degree of certainty, Zoophycos and Chondrites.

\section{ZOOPHYCOS}

Zoophycos has been recorded in cores from Sites 203, $205,206,208$, and 210 . The sediment type in which it mainly occurs is biogenic ooze, but it also occurs in almost pure pumiceous lapilli tuff (Site 205) and in mixtures of biogenic ooze and terrigenous clay (Site 210).

Zoophycos has been known for over a hundred years. It has been described under various names, such as Fucoides, Spirophyton, Taonurus, etc. (see Häntzschel, 1962; Bischoff, 1968; Taylor, 1967). Its origin has been subject to much speculation. A wide variety of causative hypotheses have been suggested, ranging from organic, both plant and animal, to nonorganic (for reviews, see Taylor, 1967; Lewis, 1970). Its origin and ecological characteristics are still open to debate, as was shown by contributions to a recent symposium on trace fossils (Crimes and Harper, 1970).

Most authors, however, now seem to agree that Zoophycos is the foraging burrow of a polychaete annelid (Bischoff, 1968; Rodriguez and Gutschick, 1970; Simpson, 1970).

Much of the controversy may be due to the fact that specimens described by various authors differ in preservation and morphology. Differences in sediment type may also play a role. Differences in morphology may reflect the existence of different species. Some authors have gone to great lengths to classify different genera and species (e.g., Plicka, 1970).

It is not the object of this paper to enter into discussion on classification. I will concentrate on the description of the specimens observed in our deep-sea cores and make a few comments related to these observations.

It must first be established that the ichnofossil I am discussing can indeed be called Zoophycos. To do this I have put together something like a "common denominator" description of Zoophycos from the literature.

The burrow consists of a "spreite" (sheet or web) wound in a helical fashion around a central axis that is perpendicular to the bedding. The diameter of the windings can vary. It can be as large as one meter. Sometimes they increase downwards. The spreite can be either left or right winding. The number of windings can vary from only one to several. The circumference of the windings can be circular or lobate. In some species a marginal tube borders the spreite along the outside. In horizontal section the spreite shows curved lamellae. In cross section these lamellae are lunate, resembling "meniscus burrows."

Enough of the above characteristics are present in our specimens to identify them as Zoophycos. They consist of a vertical axis around which a spreite is wound (Figure 5). The windings are regularly spaced (Figures 3 and 6), and as many as six windings have been observed (Figure 6). In horizontal cross section the spreite shows curved lamellae (Figure 8). In vertical cross section these lamellae are lunate (also called "crescentic bands" by Taylor, 1967; Figure 7). The spreite sometimes has a marginal tube (Figures 8 and $10)$.

Our specimens have additional characteristics of general interest.

1) The lunate structure of the spreite is convex in the direction in which the lamellae are concave.

2) According to Bischoff (1968), the lamellae meet the marginal tube at an acute angle. In our Figure 8, however, both are virtually concentric.

3) The marginal tube is not always visible in cross section. Such is, for instance, the case in Figure 7. This sample, however, broke along that winding, and the marginal tube stands out in relief on the fracture surface (Figure 8).

4) The lamellae stand out as strings of beads (Figure 8). Bischoff reports small elongate impressions, oriented at right angles to the lamellae. He interprets these as impressions from animal parapods, which are equipped with specially shaped bristles to work the sediment. The "beads" in our specimen may also be due to parapod action. However, they could just as well represent fecal pellets. Other authors also have suggested that the lunate structure represents the packing of fecal pellets (Seilacher, 1967; Lewis, 1970). Figure 9 shows more elearly the presence of fecal pellets in the burrow. However, this particularly burrow differs slightly from the others depicted in being more bulbous in crosssection. In this aspect on the other hand, it closely resembles specimens (interpreted as 


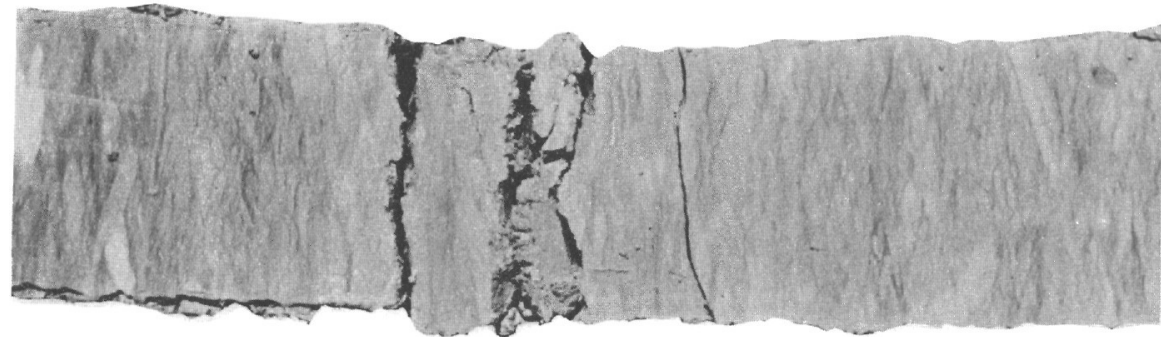

Figure 1. Section 210-33-6. Intense bioturbation, resulting in a 'bird's-eye maple' texture. The sediment is a clay-rich nanno ooze. Length of label is $9 \mathrm{~cm}$.

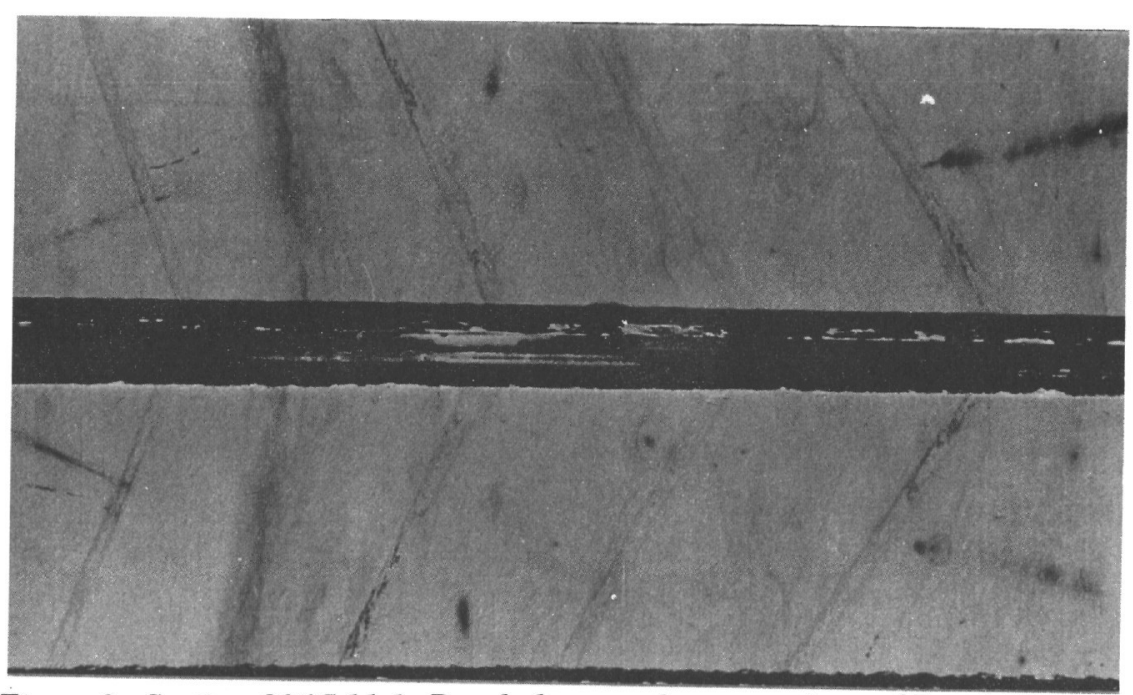

Figure 3. Section 206C-11-1. Regularly spaced cross sections of Zoophycos spreiten. Both halves of the core are shown. The sediment is a clay-bearing nanno ooze. Core diameter is $6 \mathrm{~cm}$.

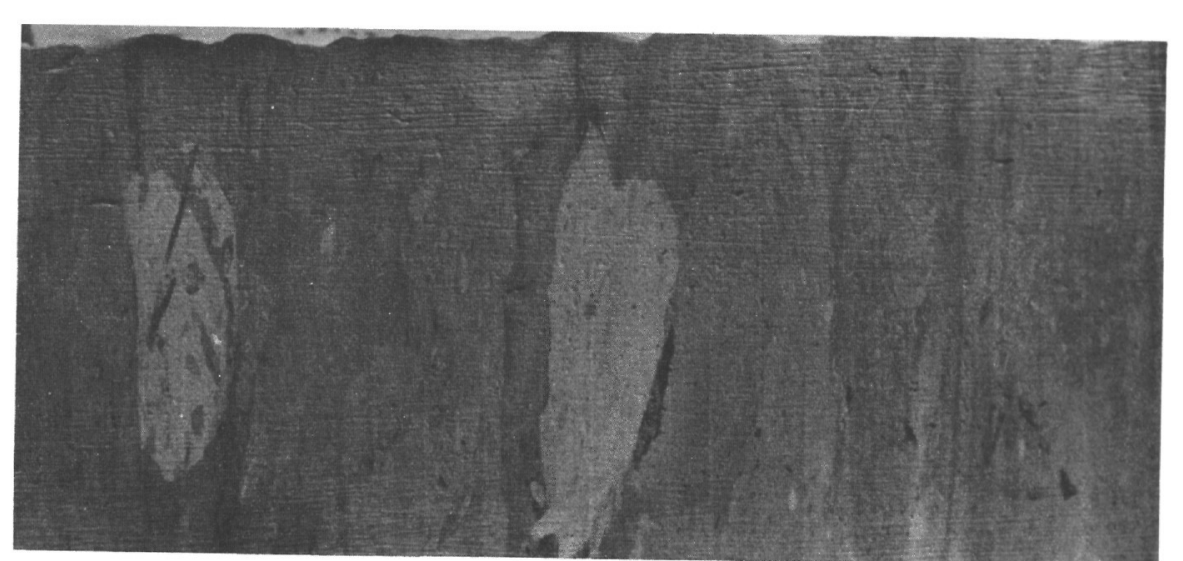

Figure 2. Section 208-28-4. Intense bioturbation. Note the two stages of burrowing. The sediment is a glass shard and diatom-bearing sponge spicule rad nanno chalk. Length of label is $9 \mathrm{~cm}$.

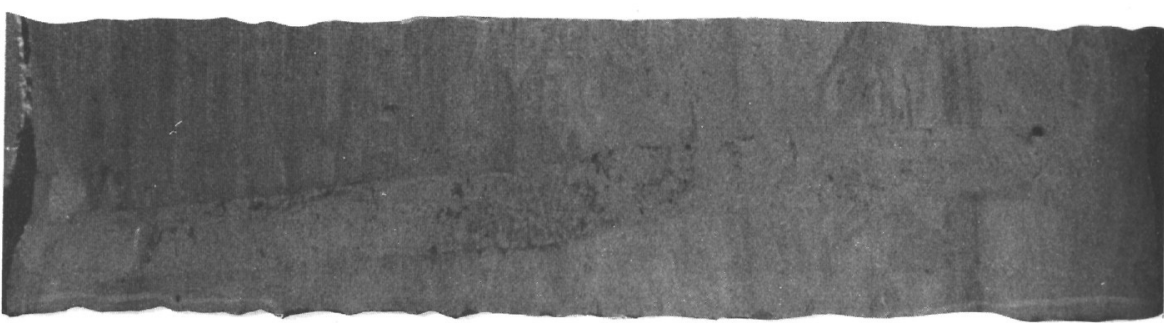

Figure 4. Section 208-29-5. Vertical section through an exceptionally long vertical burrow. The sediment is a rad sponge spicule nanno chalk. Core diameter is $6 \mathrm{~cm}$. 


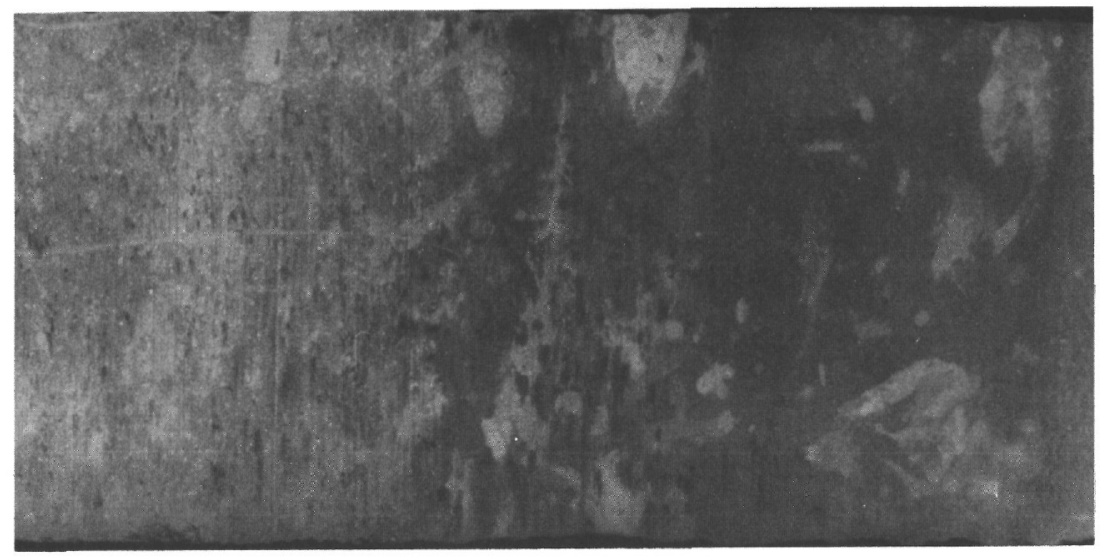

Figure 5. Section 204-6-1, showing the central axis of a Zoophycos burrow. Note spreiten, branching from the central axis. One spreite shows a change in "direction" of the lunate laminae (vertical section). The sediment is a nanno glass shard ash. Core diameter is $6 \mathrm{~cm}$.

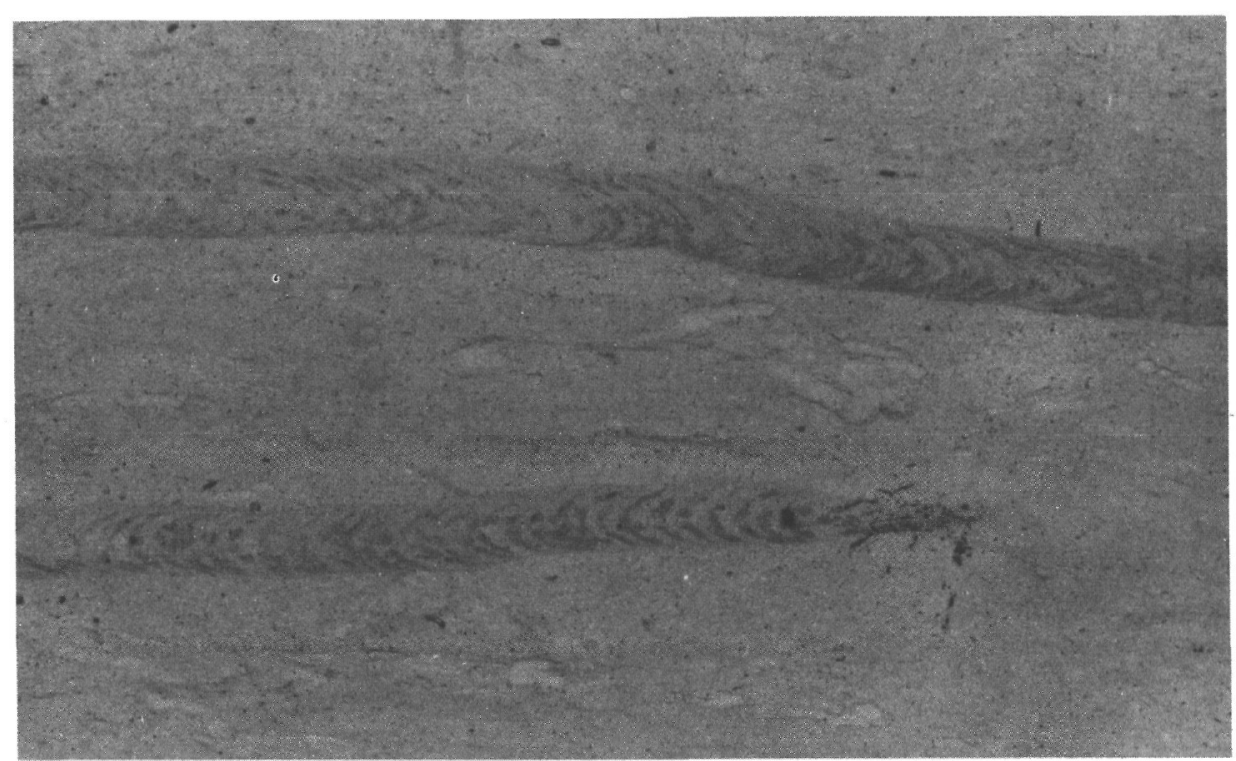

Figure 7. Section 206C-11-3. Vertical section through two Zoophycos spreiten. Note the concentration of pyrite at the periphery of one of the spreiten. A horizontal section of one of these spreiten is shown in photograph represents $6 \mathrm{~cm}$.

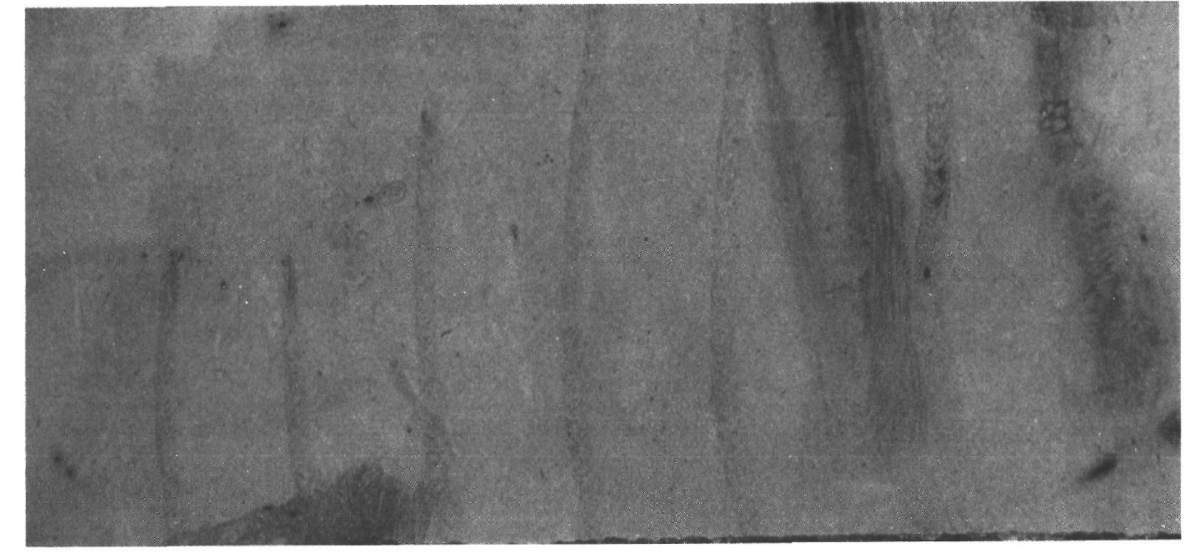

Figure 6. Section 206C-8-3. Regularly spaced cross sections of Zoophycos spreiten. The peripheries of three spreiten are shown. The sediment is $a$

foram-bearing clay-rich nanno ooze. Length of label is $9 \mathrm{~cm}$.
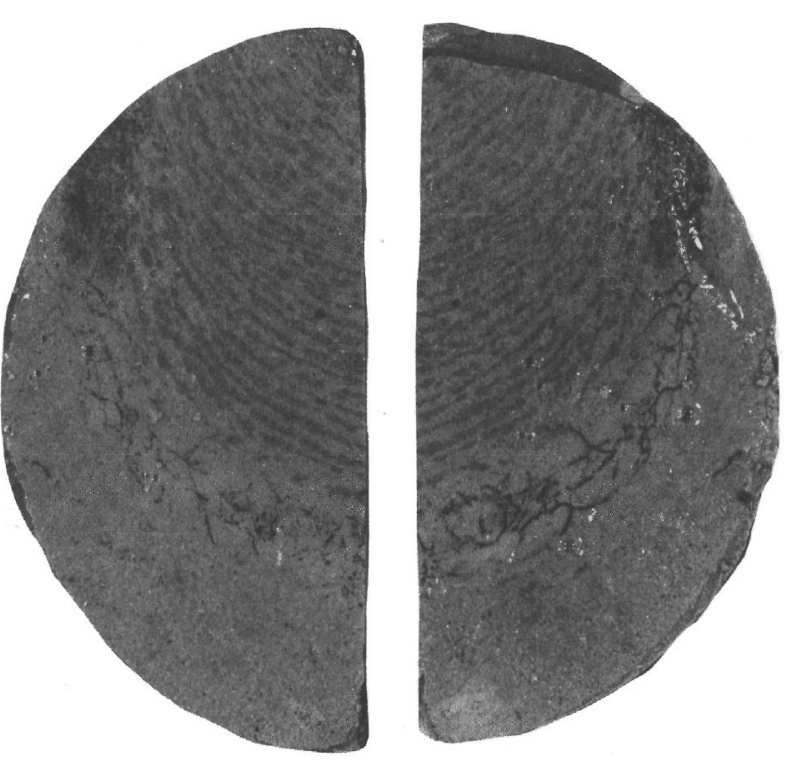

Figure 8. The same sample as in Figure 7. Horizontal section of the smaller spreite. Both sides are shown. "Bead string" lamellae and marginal tube are concentric. Note pyrite concentration in marginal tube. Core diameter is $6 \mathrm{~cm}$. 
Zoophycos) illustrated by Seilacher (1967, pl. I-E) and Taylor (1967, fig. 7-a).

5) If the lunate cross sections of the spreite are a packing feature, it would support Bischoff's (1968) theory that the animal (which he considers to be a polychaete worm) consists of more than one part (Bischoff thinks three). One part stays in the vertical axis, while another part (with parapods?) works the sediment sideways around the axis in a helical fashion, packing the sediment behind it. This would mean that the direction of feeding is towards the convex side of the lamellae as seen in horizontal plan. In Figure 8, this would be towards the marginal tube.

6) In some specimens, pyrite is concentrated within the burrow. Maximum concentration, however, is at the periphery of the windings (Figures 7 and 10). In Figure 8 we can see that the pyrite concentration coincides with the marginal tube. The pyrite may have been formed by bacterial action after the animal died. If this is so, part of the animal occupied the marginal tube at the moment of its death. In the two examples given (Figures 7 and 10), the pyrite concentration is at the periphery of the last winding (the Zoophycos of Figure 10 showed five windings in the core). The lamellae would then represent former positions of the marginal tube, which again would explain why lamellae and marginal tube are concentric.

7) A puzzling feature is the change in "direction" shown by the curvature of the lunate structure from one cross section of the spreite to the next (Figure 7). Two explanations come to mind. First, each spreite belongs to a different burrow. Because only parts of the burrows are exposed in the cores, this cannot be established. Second, the animal changed its feeding direction. In other words, it changed from left winding to right winding (or vice versa). However, unless the spreiten are almost horizontal, one would expect a change in slope.

A change in "direction" has also been observed within the cross section of a single winding (Figure 5). A similar feature was also observed bu Dr. D. W. Lewis (University of Cantebury) in a Zoophycos specimen from New Zealand (Figure 11). If we accept the theory that the lunate structure is a result of the packing of sediment, and thus indicates the feeding direction, this feature is difficult to explain. No horizontal sections are available to assist in the solution of this problem. More work will be needed.

8) Sporadic Zoophycos-type burrows display an erratic configuration (Figure 13). They resemble Zoophycos in that the burrows are planar (not tubular) and that the transverse cross sections display a lunate structure.

Zoophycos has been reported from various localities in New Zealand (Stevens, 1968; Webby, 1969; Lewis, 1970). Dr. Lewis kindly showed me specimens from his collection. The example in Figure 11 is very similar to the specimens from our deep-sea cores. Note especially the regular spacing and lunate structure of the spreiten. In plan view this specimen looks like those in Figure 12, which clearly are Zoophycos. This comparison support the identification of our deep-sea core specimens as Zoophycos.

\section{CHONDRITES}

Less problems seem to exist in the interpretation of the ichnofossil Chondrites. Simpson's (1957) classical work on Chondrites is widely accepted.
The basic characteristics of Chondrites are as follows. It consists of small (a few $\mathrm{mm}$ ) tubular burrows, which branch in a plant-like fashion (Figure 14; Simpson, 1957; Frey and Howard, 1970). They start at a sediment interface (originally sediment-water interface) and continue downwards. The burrows are filled with sediment from above the interface (Simpson, 1957; Kennedy, 1970). The sediment in the burrow may differ from the overlying sediment. This has been interpreted to indicate removal of the original overlying sediment by erosion (Simpson, 1957). The feature occurs sporadically in cores from Site 210. The author has been shown similar examples in the (Cretaceous) Bavarian Flysch (Germany) by Dr. R. Hesse (see also Hesse, 1972).

Though the animal works downwards from the interface, its main feeding activity is horizontal. Vertical sections of burrowed sequences therefore show a typical mottling, being cross sections of single tubes; few sections show branching burrows (Figures 15 and 16; Kennedy, 1970, pl. 1-d).

Simpson (1957) interprets Chondrites as a trace fossil produced by an animal on or just below the sea floor, driving tunnels from a fixed base-point with the aid of an extensible proboscis-like organ. Living animals, whose behavior most closely resembles the ethological interpretation of Chondrites, are sipunculoid worms.

Chondrites burrows have been observed in cores from two sites, 203 and 210. In 203 they occur in a clay-rich nanno ooze. In 210 they occur in nanno ooze and terrigenous clay sediments. That Chondrites has not been observed in other cores may be a function of the homogeneity of the sediment. Chondrites is detected mainly because of the difference in color between the host sediment and the burrow fill. It easily escapes detection in uniformly white biogenic ooze.

Most of the characteristics of Chondrites can be seen in our cores. As all core sections are vertical, the sediment has a mottled appearance and only a few branching burrows are seen (Figures 15, 16, and 18). The filling of burrows with sediment from above is very well illustrated in Figures 16 and 17 . The rapid alternation of sediment colors in the cores from Site 210 , from pure white nanno ooze layers to dark gray detrital-graded rhythms, lends itself particularly well to the observable preservation of ichnofossils.

\section{PALEOBATHYMETRY}

Many attempts have been made to deduce paleobathymetry from either single ichnogenera or assemblages of them. Seilacher, in Seilacher (1967) and Seilacher and Meischner (1964), introduced the concept of "ichnofacies." According to him, there is a change in behavior of ichnofauna communities with depth. In shallow water the animals are mainly suspension feeders and build relatively deep, vertical burrows with a spreite construction. With increasing water depth, the behavior of ichnofauna changes from suspension feeding to sediment feeding, and the attitude of the burrows becomes more horizontal (including grazing traces). Zoophycos is an important genus in the communities characterizing the two deepest ichnofacies (Zoophycos-facies and Nereites-facies). Judging from Seilacher's illustrations (1967, fig. 3) the Zoophycos illustrated for the Zoophycos-facies, is the species known as 


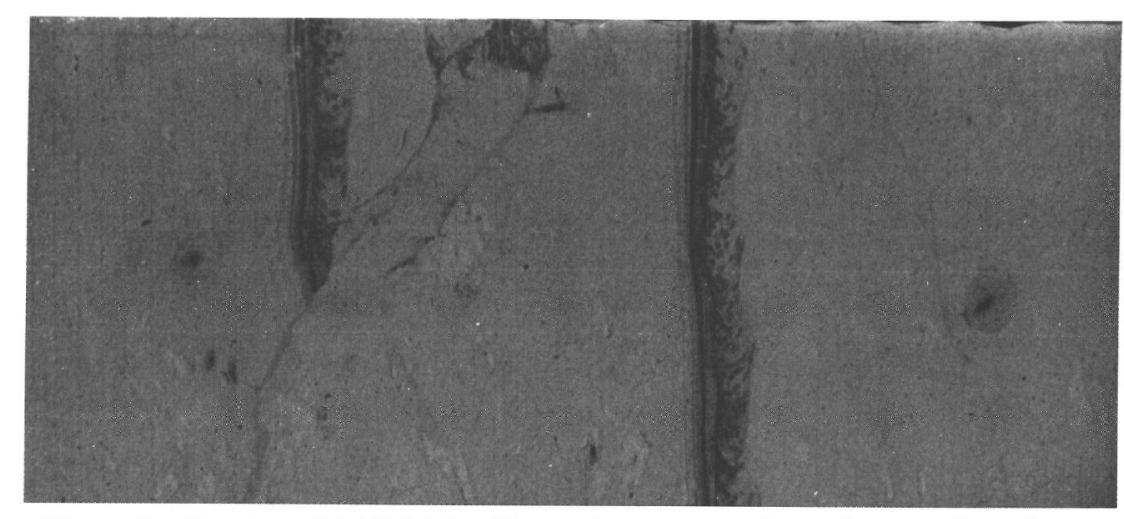

Figure 9. Section 206C-11-3. Vertical section through two Zoophycos spreiten, clearly showing fecal pellets, packed in a lunate fashion. Dark continuous bands are probably not bedding, but "Liesegang rings" due to secondary sulphite enrichment. Note crossing burrow. The sediment is a clay-bearing nanno ooze. Length of label is $9 \mathrm{~cm}$.
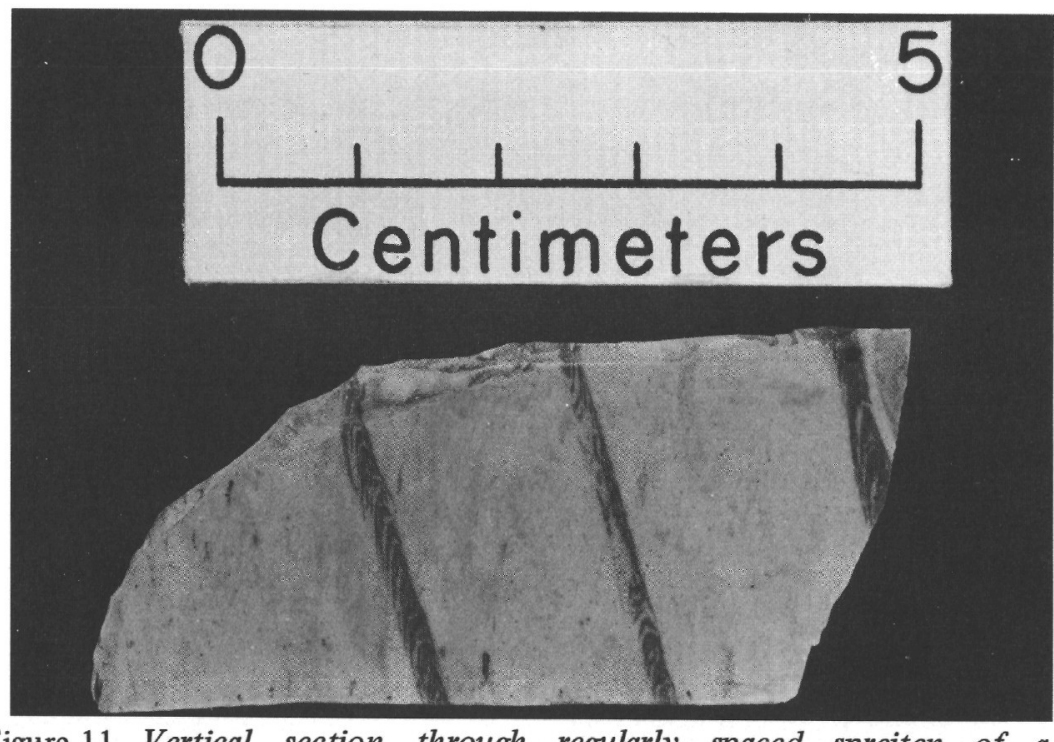

Figure 11. Vertical section through regularly spaced spreiten of a Zoophycos from Tertiary limestone, South Island, New Zealand. Note change in direction of curvature of the lunate structure in the middle spreite.

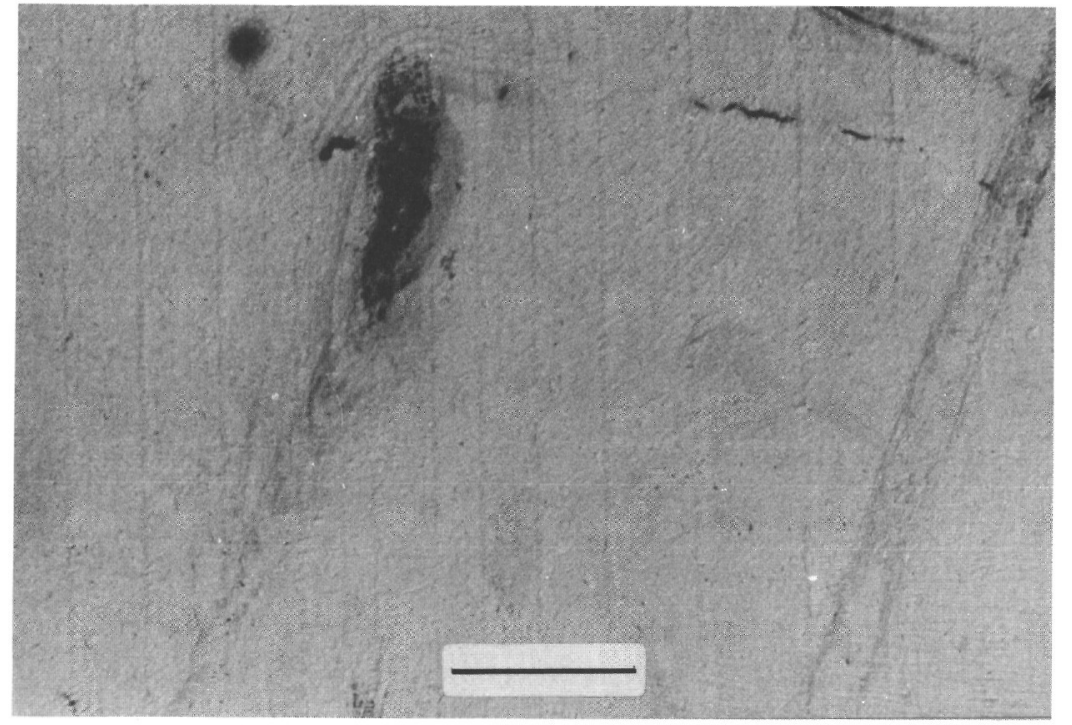

Figure 10. Section 206C-11-1. Vertical section of the periphery of a Zoophycos spreite. Note the concentration of pyrite at the periphery (marginal tube?). The sediment is a clay-bearing nanno ooze. Scale bar represents $1 \mathrm{~cm}$.

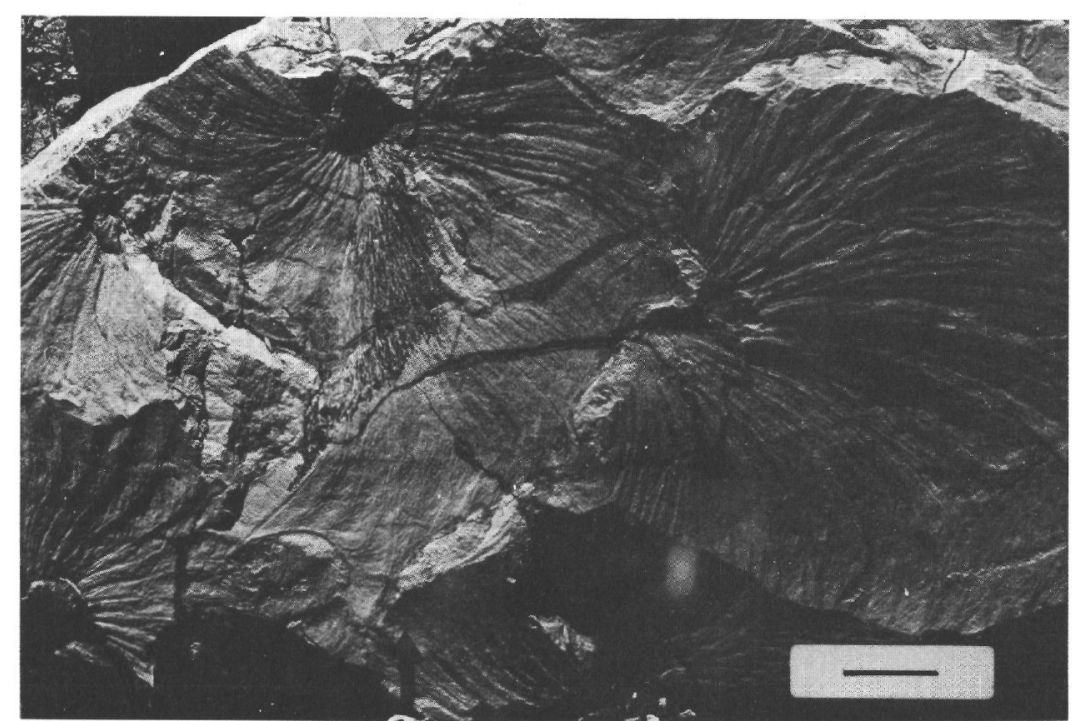

Figure 12. Plan view of Zoophycos ichnofossils; a vertical section from similar ichnofossils is shown in Figure 11. Scale bar represents $12 \mathrm{~cm}$. Figures 11 and 12 by courtesy of Dr. D.W. Lewis, University of Canterbury, Christchurch, New Zealand. 


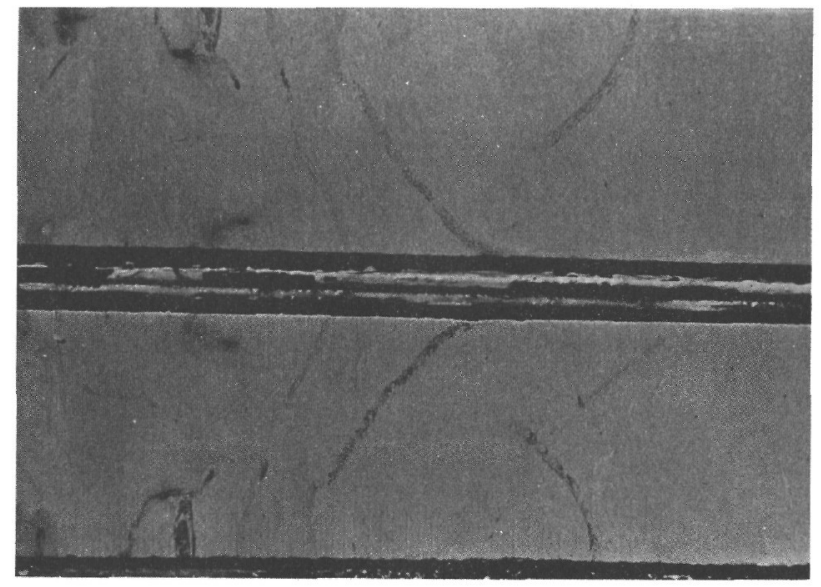

Figure 13. Section 206C-11-1. Vertical section through irregular Zoophycos-type burrows. Both halves of core are shown. The sediment is a clay-bearing nanno ooze. Core diameter is $6 \mathrm{~cm}$.

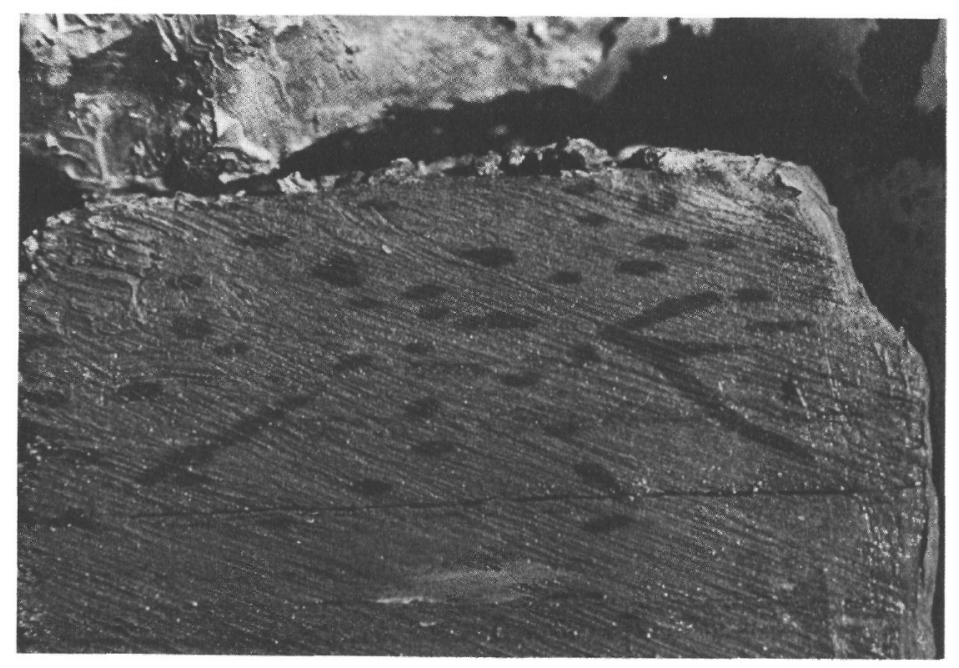

Figure 15. Section 210-21-1. Vertical section through Chondrites burrows in nanno ooze. The burrows are filled with darker sediment from the overlying graded bed. Note branching of burrows. Length of photograph represents $6 \mathrm{~cm}$.

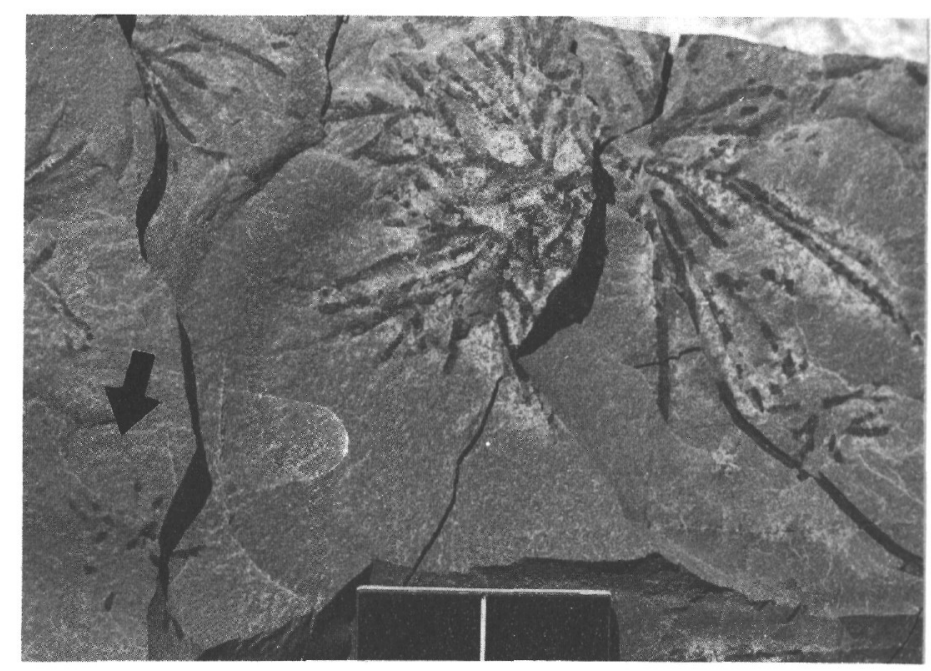

Figure 14. Plan view of Chondrites. Note also some transverse sections through Chondrites tubes (arrow). Bavarian Flysch (Cretaceous) near Bad Tölz, Bavaria, Germany. Scale in cm.

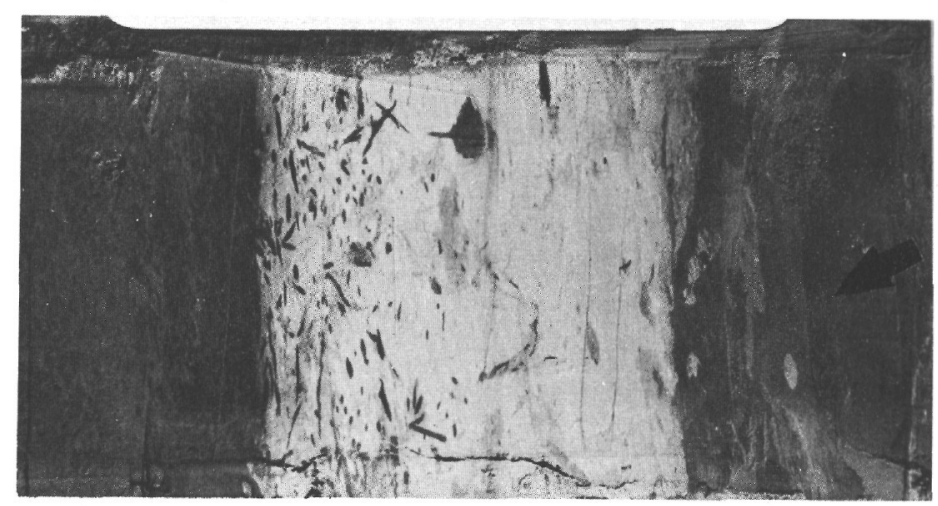

Figure 16. Section 210-25-4. Vertical section through a nanno ooze layer (light colored), intercalated between two graded beds. Chondrites burrows in the nanno ooze layer are filled with dark, silty sediment from the overlying graded bed. Note Zoophycos spreite in the top of the underlying graded bed (arrow). Length of label is $9 \mathrm{~cm}$. 


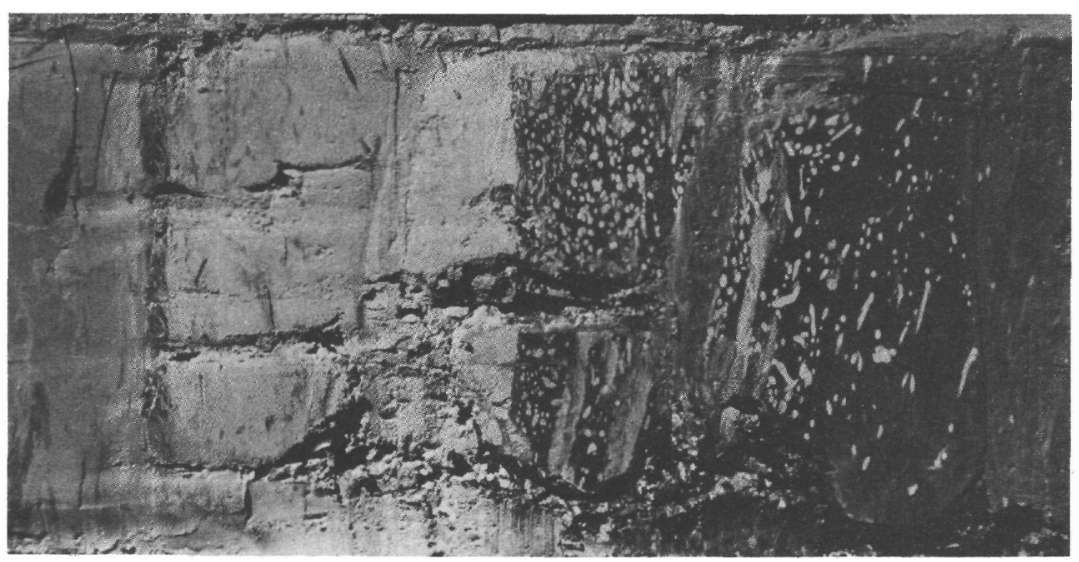

FIG. 17

Figure 17. Section 210-27-2. Chondrites burrows in the top of a graded bed. The burrows are filled with light-colored sediment from the overlying nanno ooze layer. Note Zoophycos burrow in nanno ooze layer. Length of label is $9 \mathrm{~cm}$.

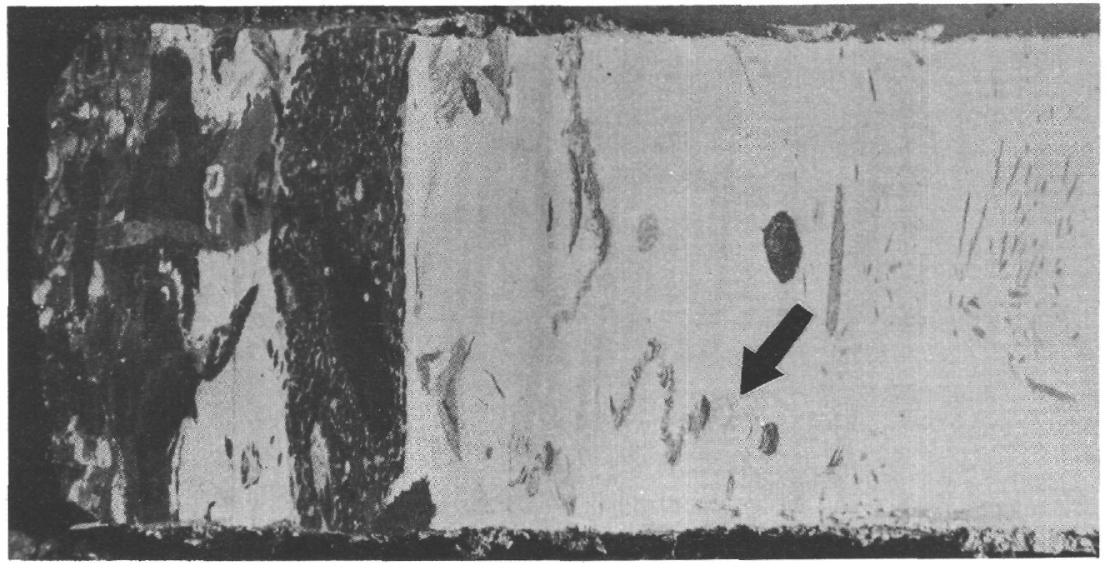

Figure 18. Section 210-29-3. Mixing of nanno ooze and terrigenous silty clay by bioturbation. Note highly mottled horizon below top of section and Chondrites burrows in the nanno ooze. One burrow somewhat resembles Teichichnus (arrow). Core diameter is $6 \mathrm{~cm}$.

cauda-galli (see Taylor, 1967). The species depicted as representative of the Nereites-facies are the more common conical and helical types. According to Simpson (1970), however, cauda-galli is not a separate species, but an incomplete part of a lobate Zoophycos. If this is so, the bathymetric range of Zoophycos would be that of both Zoophycos- and Nereites-facies.

The ichnofacies concept is an imaginative one which could prove to be a useful tool in ecological reconstructions. However, many of its detailed concepts are still open to discussion (see, for instance, Gregory, 1969; Häntzschel, 1970; van der Lingen, 1970). Seilacher conceived his ideas mainly from fossil sediments now exposed on land. His Nereites-facies, for instance, was based mainly on observations in flysch-type ("turbidite") sediments. An a-priori deep-water origin was accepted for such sediments. However, such a premise is open to discussion (van der Lingen,
1969, 1970). Difficulties also arise when dealing with carbonate sediments (Rodriguez and Gutschick, 1970).

Many authors have assigned a shallow-water origin to specific Zoophycos occurrences (Simpson, 1970; Hecker, 1970; Frey and Howard, 1970; Plicka, 1970).

It is only in recent years that information has become available from deep-sea cores and deep-sea photography. No doubt these will contribute valuable information to be incorporated in the ichnofacies concept.

The paleobathymetry indicated for the Zoophycos in our cores is based on the paleobathymetry inferred for foraminifera and nannofossils in the same intervals. The latter range from mid-bathyal to abyssal. It should be stressed however that these estimates do not represent bathymetric limits.

According to Seilacher and Meischner (1964), Chondrites is not diagnostic for any particular ichnofacies. 
It has indeed been found in many different environments. It is common in deep water as well as in shallow-water sediments. It often occurs together with Zoophycos (Figures 16 and 17). The paleobathymetric estimates for the specimens in our cores (obtained in the same way as for Zoophycos) range from midbathyal to abyssal.

\section{ACKNOWLEDGMENTS}

The author benefitted from discussion with Dr. D. W. Lewis (Geology Department, University of Canterbury) on Zoophycos. Dr. Lewis also gave permission for the reproduction of two of his photographs of the New Zealand Zoophycos (Figures 11 and 12). Dr. P. B. Andrews (New Zealand Geological Survey) kindly read the manuscript and offered many suggestions for its improvement. Messrs. G. W. Richards (New Zealand Geological Survey) and A. L. Smith (Geology Department, University of Canterbury) printed the photographs. Miss C. M. Johnstone (New Zealand Geological Survey) typed the final manuscript.

\section{REFERENCES}

Bischoff, B., 1968. Zoophycos, a polychaete annelid, Eocene of Greece. J. Paleontol. 42 (6), 1439.

Crimes, T.P. and Harper, J.C. (Eds.), 1970. Trace Fossils. Proc. Intern. Conf. Liverpool. Liverpool (Seel House Press), $547 \mathrm{p}$.

Frey, R.W. and Howard, J. D., 1970. Comparison of Upper Cretaceous ichnofaunas from siliceous sandstones and chalk, Western Interior Region, U.S.A. In Trace Fossils. Crimes, T. P. and Harper, J. C. (Eds.). Liverpool (Seel House Press), 141.

Gregory, M. R., 1969. Trace fossils from the turbidite facies of the Waitemata Group, Whangaparaoa Peninsula. Auckland. Trans. Roy. Soc. New Zealand. 7 (1), 1.

Häntzschel, W., 1962. Trace fossils and problematica. In Treatise on Invertebrate Paleontology. Part W, Miscellanea. Moore, R. C. (Ed.). Geol. Soc. Am., 177. 1970. Star-like trace fossils. In Trace Fossils. Crimes, T. P. and Harper, J. C. (Eds.). Liverpool (Seel House Press), 201.
Hecker, R. Th., 1970. Palaeoichnological reserach in the Palaeontological Institute of the Academy of Sciences of the U.S.S.R. In Trace Fossils. Crimes, T. P. and Harper, J. C. (Eds.). Liverpool (Seel House Press), 215.

Hesse, R., 1972. Turbiditic and non-turbiditic mudstones of flysch sections (abstract). Intern. Geol. Congr., 24th, Sec. 6, 116.

Kennedy, W. J., 1970. Trace fossils in the Chalk environment. In Trace Fossils. Crimes, T. P. and Harper, J. C. (Eds.). Liverpool (Seel House Press), 263.

Lewis, D. W., 1970. The New Zealand Zoophycos. New Zealand J. Geol. Geophys. 13 (2), 295.

Plicka, M., 1970. Zoophycos and similar fossils. In Trace Fossils. Crimes, T. P. and Harper, J. C. (Eds.). Liverpool (Seel House Press), 361.

Rodriguez, J. and Gutschick, R. C., 1970. Late Devonianearly Mississippian ichnofossils from Western Montana and Northern Utah. In Trace Fossils. Crimes, T. P. and Harper, J. C. (Eds.). Liverpool (Seel House Press), 407.

Seilacher, A., 1967. Bathymetry of trace fossils. Marine Geol. 5 (5/6), 413.

Seilacher, A. and Meischner, D., 1964. Fazies-Analyse im Paläozoikum des Oslo-Gebietes. Geol. Rundschau 54, 596.

Simpson, S., 1957. On the trace-fossil Chondrites. Quart. J. Geol. Soc. London 112, 475.

1970. Notes on Zoophycos and Spirophyton. In Trace Fossils. Crimes, E. P. and Harper, J. C. (Eds). Liverpool (Seel House Press), 505.

Stevens, G. R., 1968. The Amuri Fucoid. New Zealand J. Geol. Geophys. 11 (1), 253.

Taylor, B. J., 1967. Trace fossils from the Fossil Bluff Series of Alexander Island. British Antarctic Survey Bull. $13,1$.

van der Lingen, G. J., 1969. The turbidite problem. New Zealand J. Geol. Geophys. 12 (1), 7. 1970. The turbidite problem: a reply to Kuenen. New Zealand J. Geol. Geophys. 13 (3), 858.

Webby, B. D., 1969. Trace fossils Zoophycos and Chondrites from the Tertiary of New Zealand. New Zealand J. Geol. Geophys. 12 (1), 208. 